\title{
Use of surgical mesh of different compositions in the correction of the abdominal wall defect in rats
}

\section{Emprego de telas cirúrgicas de diferentes composições na correção de defeito da parede abdominal de ratos}

Ana Cristina Isa, ACBC-PR'; Jorge Eduardo Fouto Matias, ACBC-PR'; Cella Toshie Yamamoto'; Rosana Hapsi Isa; Antônio Carlos Ligocki Campos, TCBC-PR'i ; Júlio Cezar Ului Coelho, TCBC-PR'

\section{A}

\begin{abstract}
Objective: To analyze the performance of two surgical meshes of different compositions during the defect healing process of the abdominal wall of rats. Methods: thirty-three adult Wistar rats were anesthetized and subjected to removal of an area of $1.5 \mathrm{~cm} \times 2 \mathrm{~cm}$ of the anterior abdominal wall, except for the skin; 17 animals had the defect corrected by edge-to-edge surgical suture of a mesh made of polypropylene + poliglecaprone (Group U - Ultrapro ${ }^{\mathrm{TM}}$ ); 16 animals had the defect corrected with a surgical mesh made of polypropylene + polidioxanone + cellulose (Group P - Proceed ${ }^{\mathrm{TM}}$ ). Each group was divided into two subgroups, according to the euthanasia moment (seven days or 28 days after the operation). Parameters analyzed were macroscopic (adherence), microscopic (quantification of mature and immature collagen) and tensiometric (maximum tension and maximum rupture strength). Results: there was an increase in collagen type I in the Proceed ${ }^{\mathrm{TM}}$ group from seven to 28 days, $p=0.047$. Also, there was an increase in the rupture tension on both groups when comparing the two periods. There was a lower rupture tension and tissue deformity with Proceed ${ }^{\mathrm{TM}}$ mesh in seven days, becoming equal at day 28 . Conclusion: the meshes retain similarities in the final result and more studies with larger numbers of animals must be carried for better assessment.
\end{abstract}

Key words: Abdominal Wall/surgery. Hernia, Abdominal. Surgical Mesh. Tissue Adhesions.

\section{INTRODUCTION}

Since long ago, Surgery searches for appropriate solutions $S$ for lasting correction of hernias and abdominal wall defects with loss of substance. In the presence of large abdominal wall defects, approaching the defect edges is impractical and unwise. Over time, there have been various proposals to deal with such defects, from the use of tissues originating from various topographies of the patient to the use of synthetic material prostheses able to resist tension.

Surgical meshes are being improved for better acceptance of the organism with respect to its healing and inflammatory response ${ }^{1-3}$.

The Ultrapro ${ }^{\mathrm{TM}}$ mesh is composed of low density, partially absorbable, monofilament yarns, with macropores 3-4 mm in size developed with a combination of equal parts of polypropylene, a non-absorbable material, and poliglecaprone, an absorbable one (Ultrapro ${ }^{\mathrm{TM}}$, Johnson \& Johnson, USA). The Proceed ${ }^{\mathrm{TM}}$ mesh comprises separating multilayer fabrics, consisting of monofilament yarns with macropores and of a low density polypropylene mesh between two polydioxanone layers, one layer of regenerated oxidized cellulose (ROC), a raw material of plant origin, and absorbable polydioxanone (Proceed ${ }^{\mathrm{TM}}$, Johnson \& Johnson, USA). This mesh has an area specifically designed for contact with viscera, focusing at significantly lower adherence rates compared with meshes devoid of this feature. However, no technological advances causing less adhesions should result in impairment of other performance parameters of a surgical mesh, such as offered resistance, biocompatibility and complications rates ${ }^{4}$.

The purpose of this study is to analyze the performance of the surgical meshes Ultrapro ${ }^{\mathrm{TM}}$ and Proceed ${ }^{\mathrm{TM}}$ when used in edge-to-edge suture for correction of abdominal wall defects experimentally produced in adult rats.

\section{METHODS}

This study was conducted in the Vivarium and in the Surgery Department of Centro Universitário Positivo. We used the Guidelines for Presentation of Scientific Papers of the Federal University of Paraná (2007) and the Veterinary

1. Programa de Pós Graduação em Clínica Cirúrgica da Universidade Federal do Paraná, Curitiba, PR, Brasil; 2. Residente em Cirurgia Geral, Hospital Angelina Caron, Paraná, PR, Brasil. 
Anatomical naming (1983). The research followed the principles of animal experimentation determined by the Brazilian College of Animal Experimentation (COBEA) and the Canadian Council on Animal Care, and was approved by the Ethics in Research Committee of Universidade Positivo under the Protocol at 2-2010.

The sample consisted of 33 male Wistar rats (Rattus norvegicus albinus), weighing between $200 \mathrm{~g}$ and $300 \mathrm{~g}, 20-30$ days old, obtained in the animal vivarium of Centro Universitário Positivo.

The animals were kept in the trial environment for fifteenth days before the start of the experiment, in airconditioned rooms with digital control, with temperature ranging from $18^{\circ}$ to $20^{\circ} \mathrm{C}$, relative humidity of $65 \%$ and 12 -hour light-dark periods. They received commercial feed pellets Nuvilab-CR $1^{\text {TM }}$ (Nuvital-Curitiba / PR) ad libitum.

The animals were divided into two groups: $U$ composed of 17 animals in which we used the polypropylene and poliglecaprone surgical mesh (Ultrapro ${ }^{\mathrm{TM}}$ ). This group was subdivided into two subgroups: U7 - consisting of nine rats that were euthanized seven days after the operation; and $\mathrm{U} 28$ - with eight rats that were euthanized 28 days after the operation. The second Group, P, was composed of 16 animals in which we applied the surgical mesh composed of mixed polypropylene, absorbable polydioxanone (PDS) and ROC - regenerated oxidized cellulose (Proceed ${ }^{\mathrm{TM}}$ ). This group was subdivided into two subgroups: P7 - made up of eight rats that were euthanized seven days after the operation; and P28 - comprising eight rats to be euthanized 28 days after the operation. All animals received a $1.5 \times 2 \mathrm{~cm}$ mesh on the defect created in the abdominal wall, which also measured $1.5 \times 2 \mathrm{~cm}$. The animals were euthanized in a gas chamber.

The rats were sedated with isoflurane vaporization in glass bell jar. Upon sedation the animals received a combination of $100 \mathrm{mg} / \mathrm{kg}$ of $10 \%$ ketamine hydrochloride and $10 \mathrm{mg} / \mathrm{kg}$ of $2 \%$ xylazine hydrochloride intramuscularly. Once reached the anesthesia, the rat was positioned in supine on the operating table. The management of pain during operation was obtained by intramuscular administration of $2.5 \mathrm{mg} / \mathrm{kg}$ morphine sulfate. In the postoperative period this same analgesic scheme was employed during the first three days followed by maintenance with paracetamol orally at a dose of 20 drops to $500 \mathrm{ml}$ of consumed water ${ }^{5-12}$.

We performed trichotomy of the abdominal region followed by the cleaning / sterilization of the skin with polyvinylpyrrolidone iodine solution (PVP).

Surgical technique used: a) longitudinal xyphopubic incision in the abdominal wall, with 15 blade scalpel and cauterization of the wall bleeding vessels; b) blunt and scissors dissection between the skin and the aponeurosis and rectus abdominis; c) abdominal wall tissue exeresis involving the aponeurosis, muscle and parietal peritoneum $1.5 \times 2 \mathrm{~cm}$ in size; d) edge-to-edge suture of the surgical mesh of dimensions identical to the created defect, with 40 polypropylene suture in a continuous fashion, as illustrated in Figures 1 and 2; e) skin closure with continuous intertwined 3-0 polypropylene suture. Both groups underwent the same surgical technique, performed by the same operator.

For postoperative analgesia we administered $2.5 \mathrm{mg} / \mathrm{kg}$ intramuscular morphine every 24 hours for three days, followed by maintenance with oral paracetamol at the dose of 20 drops digested $500 \mathrm{ml}$ water, according to the vivarium protocol

Once completed the time for each group (7 and 28 days), the animals were evaluated and photographed. After euthanasia, we evaluated the external appearance

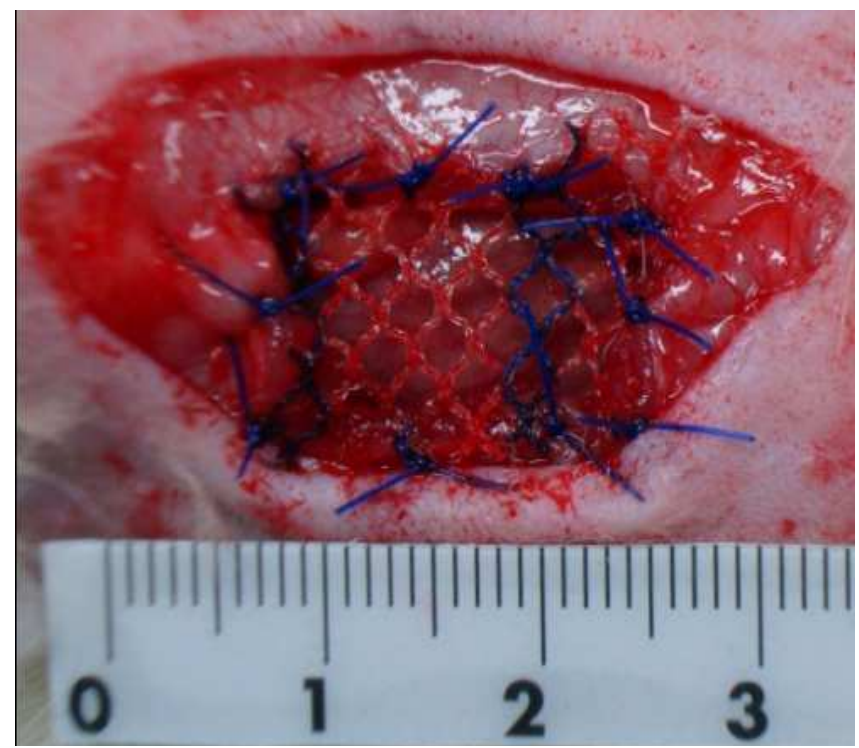

Figure 1 - Ultrapro ${ }^{T M}$ mesh placed in the abdominal wall of rats.

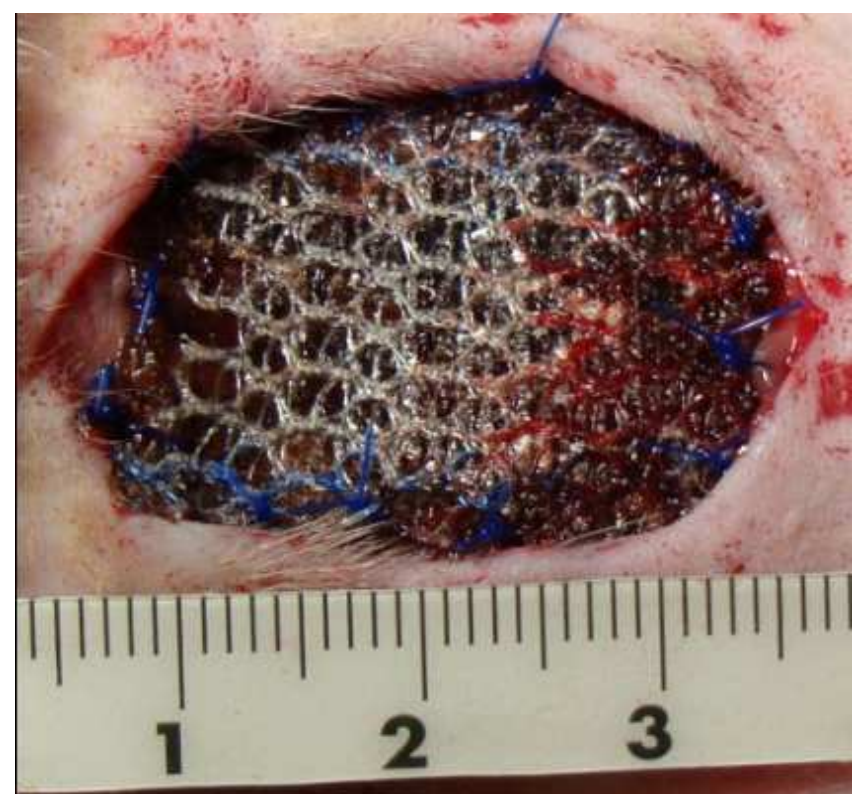

Figure 2 Proceed ${ }^{T M}$ mesh placed in the abdominal wall of rats. 
of the surgical scar and performed a U-shaped incision, with removal of the mesh with the tissue wall measuring $7 \times 1 \mathrm{~cm}$ with the trapezoid-shaped ends in the transverse direction (Figure 3). The samples were placed in vials with saline solution with the identification of the animal and immediately forwarded to the Mechanics Department of Centro Universitário Positivo, where they were submitted to the rupture tension test of evidence, the values measured in Newton $/ \mathrm{cm}^{2}$ for the tensiometry study. The other fragment was laid on a white cardboard slip of paper and placed in a vial with Bouim solution properly labeled with date, researcher name and identification of the animal, being sent to the Laboratory of Cell Biology at the Centro Universitário Positivo.

\section{Histologic processing}

The processing of the collected material for optical microscopy was performed at the Laboratory of Cell Biology at the Centro Universitário Positivo. The cuts were $4 \mathrm{im}$ thick. After 12 hours of drying they were stained with picrosirius-red F3BA (PSR).

Histological sections were stained with $\mathrm{HE}$ and analyzed by a optical microscope biological Nikkon ${ }^{\mathrm{TM}}-\mathrm{Cl}$ - LED and polarized light, with eyepieces of $22 \mathrm{~mm}$ diameter and 400 times magnification ${ }^{13-15}$.

\section{Macroscopic examination}

The presence of adhesions in the abdominal cavity was classified according to parameters described by Nair et al. ${ }^{16}$ : grade $0=$ complete lack of adherence; grade 1 = single adhesion between two organs or between an organ and the abdominal wall; grade 2 = two adhesions between organs or between organs and the abdominal wall; level 3 = more than two adhesions between organs or with the abdominal wall; or a mass of widespread adhesions of the intestine without adhering to the abdominal wall; and grade 4 = generalized adhesions between organs and the abdominal wall.

\section{Quantitative Collagen Analysis}

The PSR method consisted in the identification and quantification of mature (type I) and immature (type III)

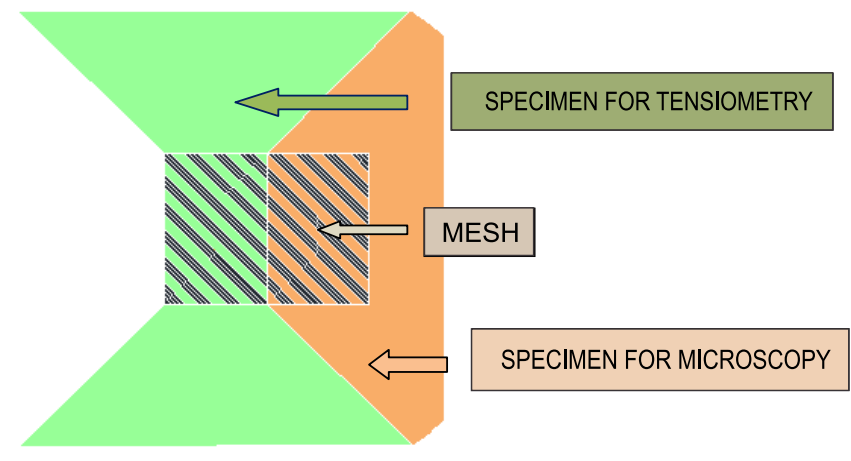

Figure 3 - Cutting scheme of surgical specimens. collagen fibers through optical microscope Olympus ${ }^{\mathrm{TM}}$, Japan, with a source of polarized light. The images were captured by a Iris CCD Sony ${ }^{\mathrm{TM}}$ camera, Japan, transmitted to a monitor, frozen and scanned by plates. Therefore, this system enabled the quantification of the area occupied by each type of collagen by predetermined field of histological section ${ }^{17}$.

The images were transmitted to a computer, previously calibrated to 18 pixels, frozen and digitized by plates, Oculus TCX ${ }^{\mathrm{TM}}$ (CoreCo). Computerized morphometric analysis was done by Pro-plus image software, version 4.5 (Media Cybernetics, São Paulo, Brazil). At 400x magnification, calibration of the system was performed by reading the normal scar area, based on the optical density of the points of resolution (pixels) that form the image. We carried out three collagen measures in each longitudinal field and other three in each transversal field.

With the same Image-Pro Plus 4.5 software, we analyzed the total area (in pixels) and the collagen percentage of type I and type III. In the RGB (Red, Blue, Green) system, we considered the thicker and strongly birefringent collagen fibers, colored in shades of red and orange, as mature (type I) collagen, and the thinner, more dispersed, frankly birefringent fibers, stained in shades of green as immature (type III) collagen. This yielded an average of these percentages in each histological section. All noncollagen substance was stained in black, the mature type I collagen was stained in yellow, red-orange and red, while the type III or immature collagen was stained in green.

\section{Tensiometry}

We evaluated the tensiometric resistance of the tissue sutured with surgical mesh in the seventh and 28th day after the operation. The specimen containing the sutured mesh and surrounding tissue was cut in the transverse direction to form two equal units, one being sent to microscopic examination and the other subjected to evaluation of the maximal tissue deformity and rupture tension measurement in Newton $/ \mathrm{cm}^{2}$. using an EMIC DL30000N extensometer. The specimen was inserted into the tensiometry apparatus and subjected to tensile strength with a $50 \mathrm{~kg}$ load cell. The grasp of the two ends of the specimen was made near the suture with the surgical mesh in the tensiometer, and subjected to a constant tension strength of acceleration speed $5 \mathrm{~mm} /$ minute until deformity and rupture of the material. The whole procedure was recorded in charts with the Tesc software version 1.10, showing the value in $\mathrm{N} / \mathrm{cm} 2$ of the maximum strength reached at the time of deformation and rupture ${ }^{18}$.

We called maximum tension the maximum strength supported by the tissue (Figure 4), by section unit $\left(\mathrm{Kgf} / \mathrm{cm}^{2}\right)$, a variable dependent on the dimensions of the resected tissue, which were standardized. Maximum tension is the greatest strength supported by the tissue throughout the test time ${ }^{18}$.

The results obtained in the study were expressed as frequencies and percentages (qualitative variables) or 
average, minimum, maximum values and standard deviations (quantitative variables). To compare the groups and time points regarding the dichotomous nominal variables we used Fisher's exact test. The comparisons of quantitative variables were made using the nonparametric MannWhitney test. Values of $p d^{\prime \prime} 0.05$ indicate statistical significance.

\section{RESULTS}

\section{Adhesions}

Adhesions were found in all animals of all subgroups, indicating a similarity between the meshes used in the study as for tissue adhesion induction.

\section{Quantification of collagen}

When comparing the $U$ subgroups we observed that on the seventh day type I collagen showed a mean of 14,003 pixels, while type III collagen averaged 34,985 pixels. On the 28th day we noted a non-significant reduction of type I collagen $(p=0.16)$ and a significant increase of collagen type III $(p=0.01)$. Comparisons between $P$ subgroups showed an average of 20,355 pixels on the

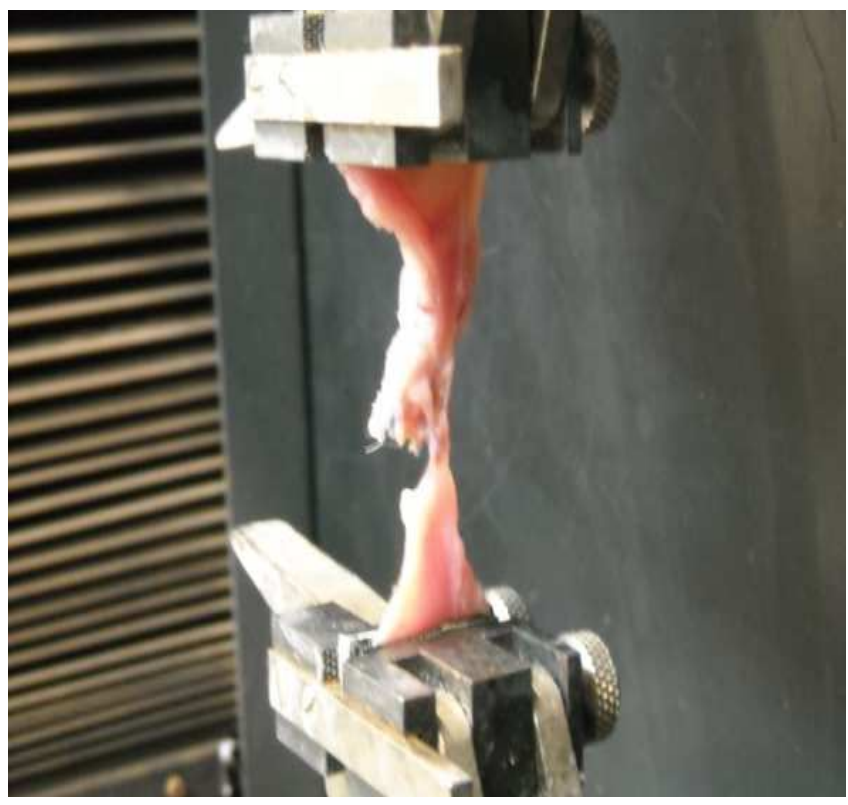

Figure 4 - Tissue fragment submitted to rupture tension. seventh day for collagen type I and 46,470 for type III. On the 28th day there was no significant increase $(p=0.20)$ of type I collagen, and a reduction with statistical difference for collagen type III ( $p=0.047$ ) (Table 1).

There were no statistically significant differences in intergroup comparisons both for type I and type III collagens when analyzed in the seven-day. However, after 28 days of the meshes' insertion, there were quantities of type I collagen significantly higher $(p=0.03)$ around the Proceed ${ }^{\mathrm{TM}}$ meshes than around the Ultrapro ${ }^{\mathrm{TM}}$ ones. Conversely, at the same time (day 28), the amount of collagen type III was significantly much higher $(p=0.0003)$ around the Ultrapro ${ }^{\mathrm{TM}}$ meshes than around the Proceed ${ }^{\mathrm{TM}}$ ones (Table 1).

\section{Tensiometry}

We noted that the two parameters monitored in the tensiometric evaluation of the samples (tissue maximum deformity and rupture tension) had similar behaviors in both intragroup and intergroup comparisons.

We found a significant increase of suture line resistance (abdominal wall-mesh interface) of the specimens over time (seven to 28 days) characterized by the statistically significant increase in the measurements, both of maximum deformity and of rupture tension, between the seventh and 28th day and for both types of mesh studied (Table 2).

Despite this, tensiometry showed interesting differences between the meshes used. We observed a distinct and statistically significant difference between the Ultrapro ${ }^{\mathrm{TM}}$ and Proceed $^{\mathrm{TM}}$ meshes in the two tensiometric parameters measured on the seventh day. Both the maximum deformity and rupture tension had significantly lower rates on the seventh day in the Proceed ${ }^{\mathrm{TM}}$ mesh subgroup (Table 2). This same comparison the 28th day did not show statistically significant difference. Therefore, the tensiometry data testify a resistance increase of the abdominal wall-mesh interface along the study period, which accumulates rapidly at the beginning with the Ultrapro ${ }^{\mathrm{TM}}$ meshes, but at the end of four weeks, the Proceed ${ }^{\mathrm{TM}}$ meshes achieve similar tensiometric performance.

\section{DISCUSSION}

The choice of the meshes used in this study is easily justified by the current demand for dual composition

Table 1 - Comparison of types I and III collagen quantification (pixels) between the study subgroups.

\begin{tabular}{lcccc}
\hline & \multicolumn{2}{c}{ ULTRAPRO® } & $(n=17)$ & \multicolumn{2}{c}{ PROCEED $(n=16)$} \\
Colagen & U7 & U28 & P7 & P28 \\
\hline TYPE I & $14,003 \pm 13,406$ & $8,264 \pm 9,775^{\circ}$ & $20,355 \pm 17,048$ & $30,431 \pm 20,281$ \\
TYPE III & $34,985 \pm 24,201$ & $62,669 \pm 12,507^{*}$ & $46,470 \pm 11,031$ & $38,873 \pm 7,180^{+}$ \\
\hline
\end{tabular}

${ }^{*} p=0.01$ compared with U7; $+p=0.047$ compared with $P 7 ;{ }^{\circ} p=0.03$ compared with $P 28 ; \bullet p=0.0003$ compared with P28 (Mann-Whitney test). 
meshes when inserted in the peritoneal cavity to prevent the formation of intra-abdominal adhesions and at the same time provide adequate tensile strength to the abdominal wall surface in contact with the muscles ${ }^{12,18,19}$

Non-absorbable meshes are preferred in repair of non-contaminated abdominal wall defects, while the absorbable meshes are preferred in the repair of abdominal wall infected defects until there is resolution of the case, when, then, may be replaced by a non-absorbable prosthesis. However, the mesh is a foreign body, a significant cause of peritoneal adhesion formation, particularly in intraperitoneal use. The non-absorbable mesh still has a higher risk of infection as an additional risk factor ${ }^{20-}$ 22. The ideal mesh maintains adequate and permanent occlusion of the abdominal wall defect, with low rates of infection and adhesion, and does not induce the formation of fistulas ${ }^{19,21-23}$.

We then used the mesh of polypropylene with polydioxanone and regenerated oxidized cellulose (Proceed ${ }^{\mathrm{TM}}$ ), designed for situations where one cannot prevent or avoid contact with the organs of the abdominal cavity. It has two absorbable layers that separate it from the tissues, reducing the intensity and extent of adhesion formation, preventing bacterial colonization by the neoperitonization that occurs in the mesh. The other mesh used (Ultrapro ${ }^{\mathrm{TM}}$ ) was developed to provide support and reinforcement to the abdominal wall with equal parts of polypropylene and poliglecaprone, which stimulates a flexible scar and promotes a multidirectional elasticity, providing the normal dynamics and physiology to the abdominal wall, but offers no physical barrier between the mesh and the viscera, and thus should be applied to the intact peritoneum. Both meshes have polypropylene in their composition, the most often employed non-absorbable material $\left.\right|^{3,2426}$

Despite the characteristics of the meshes used in this study, our results with macroscopic parameters were different from the previously found. Although the Proceed ${ }^{\mathrm{TM}}$ mesh is the only one indicated for direct contact with intraperitoneal content, both types were employed in the same way in the repair of the total abdominal wall defect produced in the rats. Therefore, one of the surfaces of the each mesh type was in contact with the viscera after correction of the defect, since all abdominal wall layers were removed when the defect was created but the skin, which stayed in contact with the other surface of the meshes.
We observed that the adhesion phenomenon was universal for both mesh types and at both euthanasia moments, which also occurred in other studies $27-29$. This occurred in spite of deploying the Proceed ${ }^{\mathrm{TM}}$ mesh cellulose surface facing the interior of the peritoneal cavity during correction of the defect, which caused us to conclude that, contrary to the expected, there was no protective effect against adhesions produced by this mesh.

\section{Microscopy}

When comparing the different staining methods for collagen analysis, it was evident that the staining with picrosirius is easy to perform and interpret, and specific to the study of tissue collagen ${ }^{27}$. The adhered amount of dye is proportional to the amount of protein present, allowing its use for collagen quantification ${ }^{28}$.

The $U$ group(Ultrapro ${ }^{\mathrm{TM}}$ ) displayed an increase of type III collagen and decrease in type I collagen when comparing the periods of seven and 28 days. In the P group (Proceed ${ }^{\mathrm{TM}}$ ) there was an increase in the average type I collagen and decreased type III one at comparison between the seventh and 28th days. We found no similar results in the literature. Studies on meshes' fixation found a progressive increase in type I / III collagen content in the seventh, 14th and 56th days 28,29 . Another author compared the polypropylene mesh with the Ultrapro ${ }^{\mathrm{TM}}$ and found no difference in collagen type I and $\mathrm{II}^{30}$, and the polypropylene meshes with different pore size showed differences in type collagen, with higher amounts in meshes with pores larger than $4 \mathrm{~mm}$, though with no differences as to type III collagen ${ }^{29}$

We believe that the quantification of type I and III collagen, when evaluated and measured by the unit used in this study, lacked minimal reliability so that we could assume as real the differences highlighted by the statistical analysis. High values of standard deviation, sometimes of the same magnitude as the medium itself, testify to a impediment heterogeneity, hampering valid conclusions on results' interpretation.

\section{Tensiometry}

We found that the $U$ group showed a tensile strength greater than the P group on the seventh day, but on the 28th day they were equal. Similar results to ours, studies have comparing three types of mesh found tensile strength similar among them at the 90th postoperative day'

Table 2 - Comparison of maximum tissue deformity (MTD) and rupture tension (RT) between the study subgroups.

\begin{tabular}{|c|c|c|c|c|c|c|c|}
\hline \multirow{3}{*}{$\frac{\text { Parameter }}{\text { MDT }\left(\mathrm{N} / \mathrm{cm}^{2}\right)}$} & \multicolumn{4}{|c|}{ ULTRAPRO $\otimes(n=17)$} & \multicolumn{3}{|c|}{ PROCEED\& $(n=16)$} \\
\hline & \multicolumn{2}{|c|}{ U7 $(n=9)$} & \multicolumn{2}{|c|}{ U28 $(n=8)$} & \multicolumn{2}{|c|}{ P7 $(n=8)$} & P28 $(n=7)$ \\
\hline & $16.72 \pm$ & $7.71 * 0$ & $24.08 \pm$ & 8.37 & $9.93 \pm$ & $4.33^{+}$ & $21.27 \pm 4.43$ \\
\hline $\mathrm{RT}\left(\mathrm{N} / \mathrm{cm}^{2}\right)$ & $9.05 \pm$ & $3.85 * 0$ & $14.82 \pm$ & 3.00 & $3.31 \pm$ & $1.86^{+}$ & $12.35 \pm 5.59$ \\
\hline
\end{tabular}

* $p<0.05$ compared with U28; $+p<0.05$ compared with $P 28 ;{ }^{\circ} p<0.05$ compared with $P 7$. 
${ }^{3}$. However, another author ${ }^{18}$ evaluated the tensile strength between different meshes and found that the polyglactine mesh is not suitable for use as fascial substitute for prolonged periods, since its tensile strength decreases after 12 weeks compared with other studied mesh (polypropylene and polytetrafluoroethylene). In another study that compared the polypropylene mesh with two new forms of expanded polytetrafluoroethylene mesh, it was concluded that the latter promote more tensile strength than the polypropylene mesh, with early tissue incorporation and low potential of adhesions, being more suitable for use in abdominal operations ${ }^{20}$.

Research on mesh made of polypropylene, PTFE, polypropylene with sodium hyaluronate and carboxymethylcellulose, polyester coated with polyethyleneglycol-glycerol, polypropylene with polyglecaprone (Ultrapro $\left.{ }^{\mathrm{TM}}\right)$, polypropylene with polydioxanone and oxidized cellulose (Proceed ${ }^{\mathrm{TM}}$ ) and polypropylene with titanium and bovine pericardium, showed that on the seventh postoperative day there was no significant difference between the meshes with respect to tensile strength, but on the 30th postoperative day tensile strength was higher in the mesh made of polyester with polyethylene-glycolglycerol ${ }^{4,12}$

In the present study we note a clear difference between the meshes regarding the speed of tensile strength acquisition when evaluated by the parameters maximum deformity and rupture tension over 28 days. As expected during the healing process, over time both groups showed increases in tensile strength from the seventh to the 28th postoperative day. But in the intergroup comparison of the seventh day, the tensile strength levels achieved by the $U$ group specimens significantly outweighed the values achieved by the P one. Such a difference over the other three weeks of observation loses any statistical value for the comparison between groups at the end of the fourth week. We believe that the behavior of the parameter tensiometry in the $\mathrm{P}$ group is explained by phenomena occurring and already described in other parameters of the current study. That is, the persistent wound healing inflammatory phase induced by the presence of local infection at the end of the first week leads to consequent delay in the wound maturation to the point of having less tensile strength in relation to another group at the same time. However, with the evolution of time and infection handled by the body, there is more favorable evolution of the healing process, with recovery of the delayed maturation as to match the tensiometric performance obtained by the other group at the end of the longest observation period.

The findings demonstrated in this research illustrate, in an exemplary manner, and contribute to the effective understanding of the vast and varied range of results available in the literature concerning the subject. The accumulation of new and varied evidence still remains of high contributory value in this fruitful field, of variables that insist on challenging the search for new knowledge in the area.

In conclusion, the meshes retain similarities in the final result and more studies with larger numbers of animals must be carried out to better assessment.

\section{R E S U M O}

Objetivo: analisar o desempenho de duas telas cirúrgicas de composições diferentes durante o processo de cicatrização de defeito de parede abdominal de ratos. Métodos: trinta e três ratos Wistar, machos adultos foram anestesiados e submetidos à retirada de parede abdominal anterior, exceto pele, com área de 1,5cmx2cm; 17 animais tiveram o defeito corrigido pela sutura borda a borda de tela cirúrgica, composta de polipropileno + poliglecaprone (Grupo U - Ultraproß); 16 animais tiveram defeito corrigido utilizando tela cirúrgica composta de polipropileno + polidioxanone + celulose (Grupo P - Proceed®). Cada grupo foi dividido em dois subgrupos, de acordo com o momento da eutanásia (sete dias ou 28 dias após a operação). Foram analisados parâmetros macroscópicos (aderência), microscópicos (quantificação do colágeno maduro e imaturo) e tensiométricos (tensão máxima e força máxima de ruptura). Resultado: houve um aumento do colágeno tipo I no grupo Proceed® do período de sete dias para o de 28 dias, com $p=0,047$. E houve um aumento na tensão de ruptura quando comparados os dois períodos, nas duas telas analisadas. Houve menor tensão de ruptura e deformidade dos tecidos com a tela Proceed® em sete dias, levando a uma igualdade com 28 dias. Conclusão: as telas conservam semelhanças no resultado final e mais estudos com número maior de animais devem ser realizados para melhor avaliação.

Descritores: Parede abdominal/cirurgia. Hérnia Abdominal. Telas Cirúrgicas. Aderências Teciduais.

\section{REFERENCES}

1. Bellón JM, Garcla-Honduvilla N, Jurado F, Garcla-Carranza A, García-Moreno F, Martín AC, et al. Use of composite protheses in the repair of defects in the abdominal wall: prosthetic behaviour at the peritoneum. Eur J Surg. 2001;167(9):666-71.
2. Bellón JM, Jurado F, Garcĺa-Moreno F, Corrales C, Carrera-San Martin A, Buján J. Healing process induced by three composite prostheses in the repair of abdominal wall defects. J Biomed Mater Res. 2002;63(2):182-90.

3. Bellón JM, Rodríguez M, García-Honduvilla N, Pascual G, Buján J. Partially absorbable meshes for hernia repair offer advantages over nonabsorbable meshes. Am J Surg. 2007;194(1):68-74. 
4. Pundek MRZ, Czeczko NG, Yamamoto CT, Pizzatto RF, Czeczko LEA, Dietz UA, et al. Estudo das telas cirúrgicas de polipropileno/ poliglecaprone e de polipropileno/polidioxanona/celulose oxidada regenerada na cicatrização de defeito produzido na parede abdominal de ratos. ABCD, arq bras cir dig. 2010; 23(2):94-9.

5. Cronin K, Jackson DS, Dunphy JE. Changing bursting strength and collagen content of the healing colon. Surg Gynecol Obstet. 1968;126(4):747-53

6. Sher W, Pollack D, Paulides CA, Matsumoto T. Repair of abdominal wall defects: Gore-Tex vs. Marlex graft. Am Surg. 1980:46(11):618-23.

7. Gottrup F. Healing of incisional wounds in stomach and duodenum. A biomechanical study. Am J Surg. 1980;140(2):296-301.

8. Marmon LM, Vinocur CD, Standiford SB, Wagner CW, Dunn JM, Weintraub WH. Evaluation of absorbable polyglycolic acid mesh as a wound support. J Pediatr Surg. 1985;20(6):737-42.

9. Zederfeldt B. Anastomotic healing. In: Eigler FW, Gross E, Vogt E. Die Anastomose an Gastrointestinathakt TM. Verlag Hameln. 1990. p:3-16.

10. van't Riet $M$, de Vos van Steenwijk PJ, Bonthuis F, Marquet RL, Steyerberg EW, Jeekel J, et al. Prevention of adhesion to prosthetic mesh: comparison of different barriers using an incisional hernia model. Ann Surg. 2003;237(1):123-8.

11. Kapan S, Kapan M, Goksoy E, Karabicak I, Oktar H. Comparison of PTFE, pericardium bovine and fascia lata for repair of incisional hernia in rat model, experimental study. Hernia. 2003;7(1):39-43.

12. Burger JW, Halm JA, Wijsmuller AR, ten Raa S, Jeekel J. Evaluation of new prosthetic meshes for ventral hernia repair. Surg Endosc. 2006:20(8):1320-5.

13. Souza JB. Evolução da cicatrização de anastomose colônicas sob a ação do diclofenaco sódico administrado no periodo perioperatório. Estudo experimental em coelhos [tese]. Ribeirão Preto: Universidade de São Paulo, Faculdade Médica de Ribeirão Preto; 1994.

14. Oliveira PG. Efeito da peritonite por Candida albicans na cicatrização de anastomoses colônicas: estudo experimental em ratos [tese]. Ribeirão Preto: Universidade de São Paulo, Faculdade Médica de Ribeirão Preto; 1995

15. Vizzotto Júnior $A O$, Noronha L, Scheffel DLH, Campos ACL. Influência da cisplatina administrada no pré e no pós-operatório sobre a cicatrização de anastomoses colônicas em ratos. J Bras Patol Med Lab. 2003; 39(2):143-9.

16. Nair SK, Bhat IK, Aurora AL. Role of proteolytic enzyme in the prevention of postoperative intraperitoneal adhesions. Arch Surg. 1974;108(6):849-53.

17. Junqueira LC, Carneiro J. Histologia Básica. $9^{a}$ ed. Rio de Janeiro: Guanabara Koogan; 1999

18. Vrijland WW, Bonthuis F, Steyerberg EW, Marquet RL, Jeekel J, Bonjer HJ. Peritoneal adhesions to prosthetic materials: choice of mesh for incisional hernia repair. Surg Endosc, 2000;14(10):960-3.

19. LeBlanc KA, Bellanger D, Rhynes KV 5th, Baker DG, Stout RW. Tissue attachment strength of prosthetic meshes used in ventral and incisional repair. A study in the New Zeland White rabbit adhesion model. Surg Endosc. 2002;16(11):1542-6.

20. Tyrell J, Silberman H, Chandrasoma P, Niland J, Shull J. Absorbable versus permanent mesh in abdominal operations. Surg Gynecol Obstet. 1989:168(3):227-32.

21. Greene MA, Mullins RJ, Malangoni MA, Feliciano PD, Richardson JD, Polk HC Jr. Laparotomy wound closure with absorbable polyglycolic acid mesh. Surg Gynecol Obstet. 1993;176(3):213-8.

22. Baycal A, Onat D, Rasa K, Renda N, Sayek I. Effects of polyglycolic acid and polypropylene meshes on postoperative adhesion formation in mice. World J Surg. 1997;21(6):579-82; discussion 582-3.

23. Jenkins SD, Klamer TW, Parteka JJ, Condon RE. A comparison of prosthetic materials used to repair abdominal wall defects. Surgery. 1983;94(2):392-8.

24. Ferrando JM, Vidal J, Armengol M, Gil J, Manero JM, Huguet $P$, et al. Experimental evaluation of a new layered prosthesis exhibiting a low tensile modulus of elasticity: long-term integration response within the rat abdominal wall. World J Surg. 2002;26(4):409-15.

25. Mathews BD, Pratt BL, Pollinger HS, Backus $C L$, Kercher KW, Sing $\mathrm{RF}$, et al. Assessment of adhesion formation to intra-abdomina polypropylene mesh and polytetrafluoroethylene mesh. J Surg Res. 2003; 114(2):126-32.

26. Conze J, Rosch R, Klinge U, Weiss C, Anurov M, Titkowa S, et al. Polypropylene in the intra-abdominal position: influence of pore size and surface area. Hernia. 2004;8(4):365-72.

27. Junge $K$, Rosch $R$, Anurov M, Titkova S, Ottinger A, Klinge $U$, et al. Modification of collagen formation using supplemented mesh materials. Hernia. 2006;10(6):492-7.

28. Grommes J, Binnebösell M, Klink CD, von Trotha KT, Junge K, Conze J. Different methods of mesh fixation in open retromuscular incisional hernia repair: a comparative study in pigs. Hernia. 2010;14(6):623-7.

29. Binnebösell M, Klink CD, Otto J, Conze J, Jansen PL, Anurov M, et al. Impact of mesh positioning on foreign body reaction model and collagenous ingrowth in a rabbit model of open incisional hernia repair. Hernia. 2010;14(1):71-7.

30. Greca FH, de Paula JB, Biondo-Simões ML, da Costa FD, da Silva $A P$, Time $S$, et al. The influence of differing pore sizes on the biocompatibility of two polypropylene meshes in the repair of abdominal defects. Experimental study in dogs. Hernia. 2001;5(2):59-64.

Received at: 15/12/2014

Accepted for publication: 25/02/2015

Conflict of interest: none.

Source of funding: none.

\section{Mailing address:}

Ana Cristina Isa

E-mail: icrisana@yahoo.com.br 